DOI: $10.19195 / 0137-1134.114 .13$

\author{
MAGDALENA PYTER \\ Katolicki Uniwersytet Lubelski Jana Pawła II \\ magdalena.pyter@kul.pl
}

\title{
SKREŚLENIE UCZNIA Z LISTY UCZNIÓW A OBOWIĄZEK SZKOLNY
}

\begin{abstract}
Abstrakt: Artykuł przedstawia zagadnienie przeniesienia lub relegacji ucznia. Jest to problem złożony. Końcowe rozstrzygnięcie zależy bowiem od wielu czynników. Podstawowymi są: typ szkoły i jej rodzaj, a także wiek ucznia, co z kolei wiąże się z pojęciem obowiązku szkolnego i obowiązku nauki. Mając na względzie, że przeniesienie, a tym bardziej usunięcie ucznia ze szkoły powoduje określone decyzje prawne, warto zapoznawać społeczność szkolną z przesłankami i konsekwencjami tych działań.
\end{abstract}

Słowa kluczowe: prawo oświatowe, obowiązek szkolny, obowiązek nauki, skreślenie ucznia, przeniesienie ucznia, postępowanie i decyzja administracyjna

\section{ZAGADNIENIA WSTĘPNE}

Artykuł 70 Konstytucji Rzeczypospolitej Polskiej statuuje prawo każdego do nauki, podkreślając, że jest ona obowiązkowa do 18. roku życia. Regulacja ta stanowi jednocześnie prawo podmiotowe $\mathrm{i}$ - jak się wydaje — można ją uznać za jedną z najbardziej doniosłych w sferze praw i wolności socjalnych, ekonomicznych i kulturalnych. Adresatem normy zawartej w art. 70 jest każda osoba. Nie ma tu wyłączeń ani ograniczeń ze względu na wiek, pochodzenie, obywatelstwo czy inne czynniki ${ }^{1}$. Uprawnienie to jest zatem adresowane do najszerszych kręgów społeczeństwa ${ }^{2}$.

Trzeba pamiętać, że ponieważ szkoły są przykładami zakładów administracyjnych $^{3}$, uczniowie zaś użytkownikami zakładu, obowiązki edukacyjne są eg-

1 S. Bułajewski, M. Dąbrowski, Wolności i prawa człowieka w Konstytucji Rzeczypospolitej Polskiej, red. M. Chmaj, Warszawa 2008, s. 176.

2 W. Skrzydło, Konstytucja Rzeczypospolitej Polskiej z dnia 2 kwietnia 1997 r. Komentarz, Kraków 1998, s. 68.

3 W tym kontekście sytuację administracyjnoprawną jednostki będą określały zarówno normy prawa zakładowego, jak i normy prawa administracyjnego materialnego. M. Brzeski, D. Tykwińska- 
zemplifikacjami stosunku administracyjnego opartego na władztwie zakładowym. Jedną z najważniejszych cech organów administrujących jest nawiązanie między organami zakładu a jego użytkownikami stosunku administracyjnoprawnego, jak też stosunku władztwa zakładowego, którego odbiciem jest zależność zakładowa. Istotą tej zależności jest natomiast poddanie się użytkownika zakładu szczególnemu reżimowi prawnemu, wiążącemu się z celem działania zakładu. Podlegając władztwu zakładowemu, użytkownik jest związany obowiązkami wynikającymi $z$ aktów wewnętrznych ${ }^{4}$. Naruszenie prawa zakładowego może się stać przesłanką do podjęcia odpowiednich czynności przez organy zakładu. Jeśli chodzi o szkoły, to najważniejszym aktem prawa wewnętrznego jest statut. Naruszenie jego norm może zatem — w formie, którą należy uznać za najbardziej dotkliwą dla ucznia — skutkować skreśleniem go z listy uczniów.

Owe założenia i ustalenia mają z pewnością zastosowanie w wypadku szkół publicznych, których organizacja i zadania są zakresem realizacji zadań publicznych, a przez to mają one kompetencje do jednostronnego kształtowania stosunków prawnych z poszczególnymi użytkownikami zakładu. Doktryna natomiast — przynajmniej częściowo - uznaje, że w kwestii szkół niepublicznych władztwo administracyjne może być problemowe ${ }^{5}$.

Kwestia skreślenia $\mathrm{z}$ listy uczniów musi być rozpatrywana w powiązaniu z zagadnieniem obowiązku szkolnego. Zgodnie z art. 35 ust. 1 ustawy z dnia 14 grudnia 2016 roku Prawo oświatowe ${ }^{6}$, ,nauka jest obowiązkowa do ukończenia 18. roku życia". Kolejny ustęp tego samego artykułu zawiera dyrektywę, zgodnie z którą „obowiązek szkolny dziecka rozpoczyna się z początkiem roku szkolnego w roku kalendarzowym, w którym dziecko kończy 7 lat, oraz trwa do ukończenia szkoły podstawowej, nie dłużej jednak niż do ukończenia 18. roku życia"7. Warto

-Rutkowska, Zakład administracyjny, [w:] Leksykon prawa administracyjnego, red. E. Bojanowski, K. Żukowski, Warszawa 2009, s. 536.

4 J. Zimmermann, Prawo administracyjne, Warszawa 2014, s. 156-157.

5 Por. P. Sztejna, Prawne aspekty obowiązku szkolnego i obowiązu nauki, „Studia Lubuskie” 2005, nr 1, s. 137.

${ }^{6}$ Dz.U. z 2017 r. poz. 59.

7 Mając na względzie wprowadzaną od 2017 r. reformę oświaty, warto przypomnieć, że de facto dopiero od dnia 1 września 2019 r. obowiązek szkolny będzie spełniany wyłącznie przez uczęszczanie do szkoły podstawowej — publicznej albo niepublicznej. Do 1 września 2019 r. (w latach szkolnych 2016/2017, 2017/2018, 2018/2019) obowiązek szkolny trwa bowiem do ukończenia gimnazjum i ośmioklasowej szkoły podstawowej. Tym samym w wymienionych latach szkolnych obowiązek szkolny spełnia się przez uczęszczanie do szkoły podstawowej i gimnazjum — publicznych albo niepublicznych. Proces ,podwójnej ścieżki” realizacji obowiązku szkolnego zakończy się wraz z końcem działalności ostatnich klas gimnazjalnych. Co do obowiązku nauki, to dopiero od 1 września 2019 r. będzie spełniany po ukończeniu ośmioklasowej szkoły podstawowej. W latach szkolnych 2016/2017, 2017/2018, 2018/2019 obowiązek nauki będzie realizowany po ukończeniu zarówno ośmioklasowej szkoły podstawowej, jak i gimnazjum. Obowiązek nauki w wymienionych latach szkolnych będzie spełniany i w szkołach ponadgimnazjalnych lub u pracodawcy, i w szkołach ponadpodstawowych, czyli w czteroletnich liceach, pięcioletnich technikach lub w dwustopniowych 
pamiętać, że zagadnienie skreślenia ucznia zawsze niesie liczne pytania, które stawiają osoby wprost zainteresowane: rodzice uczniów i uczniowie, nauczyciele, dyrektorzy szkół oraz prawnicy. O pojawiających się trudnościach w interpretacji przepisów niech świadczy chociażby wyrok Naczelnego Sądu Administracyjnego z dnia 15 lutego 2000 roku $^{8}$, którego założenia zostaną przytoczone w dalszej części tekstu.

Niniejszy tekst jest próbą odniesienia się do regulacji prawnej w zakresie prawa oświatowego, wdrożonej w 2017 roku. W szczególności odniesiono się do zagadnienia przeniesienia do innej szkoły ucznia szkoły publicznej, który podlega obowiązkowi szkolnemu. Analizie poddano także skreślenie z listy uczniów ucznia szkoły publicznej, jeśli nie jest on objęty obowiązkiem szkolnym, oraz ucznia szkoły niepublicznej, który spełnia obowiązek szkolny.

\section{PRZENIESIENIE UCZNIA OBJĘTEGO OBOWIĄZKIEM SZKOLNYM}

Artykuł 68 ust. 2 ustawy Prawo oświatowe mówi, że dyrektor szkoły może decyzją skreślić ucznia z listy uczniów. Dokonuje tego w przypadkach określonych w statucie szkoły lub placówki. Ustawa dodatkowo wymaga uchwały rady pedagogicznej oraz opinii samorządu uczniowskiego. Dopełnieniem tej normy jest ust. 3 — podstawowy dla tej części tekstu — zgodnie z którym przedstawiona sytuacja nie dotyczy ucznia objętego obowiązkiem szkolnym. W uzasadnionych przypadkach uczeń ten może zostać przeniesiony przez kuratora oświaty do innej szkoły. Treść ust. 3 wyraźnie więc wyklucza możliwość skreślenia z listy uczniów ucznia objętego obowiązkiem szkolnym. Takie rozwiązanie należy odnieść do konstytucyjnej i ustawowej gwarancji do bezpłatnego realizowania obowiązku szkolnego w szkole publicznej. Z tej racji nie można ucznia pozbawić przysługującego mu statusu. Jednocześnie ratio legis tego typu regulacji jest umożliwienie organom szkoły publicznej wyłączenie ucznia z grona uczniów danej szkoły. Chodzi zatem wyłącznie o zmianę miejsca nauczania, nie zaś o zmianę jego sytuacji prawnej. Nadal bowiem pozostaje on uczniem.

Mając to na względzie, należy jednoznacznie stwierdzić, że osoba małoletnia, która realizuje obowiązek szkolny przez uczęszczanie do publicznej szkoły podstawowej, może być jedynie skreślona z listy uczniów danej szkoły, w żadnym zaś razie pozbawiona statusu ucznia. Spełnianie obowiązku szkolnego dodatkowo zagwarantowane jest przymusem administracyjnym, albowiem zgodnie z art. 42 ust. 1 ustawy Prawo oświatowe niespełnianie przez ucznia obowiązku szkolnego

szkołach branżowych. Absolwenci szkół ponadpodstawowych, którzy nie ukończyli 18. roku życia, będą spełniać obowiązek nauki, uczęszczając na kwalifikacyjne kursy zawodowe lub do wybranej szkoły wyższej. Por. https://reformaedukacji.men.gov.pl/o-reformie/uczen-i-rodzic/realizacja-obowiazku-nauki-i-obowiazku-szkolnego.html (dostęp: 23.11.2017).

8 I SA 1463/99, LEX nr 55782. 
podlega egzekucji w trybie przepisów o postępowaniu egzekucyjnym w administracji ${ }^{9}$. Dodatkowo należy podkreślić, że i obowiązek szkolny, i obowiązek nauki pozostają w sferze stosunków administracyjnoprawnych. Oznacza to, że dana relacja prawna podmiotów odznacza się pewnymi cechami charakterystycznymi, jak chociażby obowiązkowym charakterem. Zgodnie z cechą tego typu we wspomnianych stosunkach prawo ustala $\mathrm{w}$ określonych ramach uprawnienia i obowiązki stron, strony zaś nie mogą z nich zrezygnować ani ich modyfikować. Dodatkowo w razie konfliktu rolą organu administrującego jest zastosowanie środków przymusu ${ }^{10}$.

Istotne jest także, żeby szkoła, do której uczeń zostanie przeniesiony, była tego samego typu i rodzaju co szkoła macierzysta. Postępowanie w przedmiocie przeniesienia ucznia następuje na wniosek dyrektora szkoły. Przesłankami przeniesienia ucznia są ,,uzasadnione przypadki”. Trzeba podkreślić, że mamy tutaj do czynienia z pojęciem niedookreślonym, dającym organowi podejmującemu decyzję co do przeniesienia swobodę w interpretacji hipotezy tej normy. Przeniesienia dokonuje kurator oświaty (art. 68 ust. 3 ustawy Prawo oświatowe).

Co do formy przeniesienia trzeba zaznaczyć, że wprawdzie ustawodawca nie sprecyzował, w jakiej formie powinno odbyć się przeniesienie ucznia spełniającego obowiązek szkolny do innej szkoły, jednak należy uznać, iż kurator oświaty $\mathrm{w}$ tej sprawie powinien wydać decyzję administracyjną. Zgodnie z założeniami doktryny wola organu administracji publicznej w sferze praw i obowiązków jednostki musi być wyrażona w formie decyzji administracyjnej, jeżeli przepisy prawa nie przewidują innej formy działania tego organu.

Jeśli istnieje wątpliwość co do formy załatwienia sprawy administracyjnej, należy przyjąć, że powinna być załatwiona w formie decyzji administracyjnej, jednakże koniecznym warunkiem przyjęcia takiego domniemania jest ustalenie, że istnieje sprawa administracyjna i organ administracji publicznej jest właściwy do jej załatwienia ${ }^{11}$. Orzecznictwo sądu administracyjnego wypracowało pogląd, zgodnie z którym „Pisma zawierające rozstrzygnięcia w sprawie załatwianej $\mathrm{w}$ drodze decyzji są decyzjami, pomimo nie posiadania w pełni formy przewidzianej w art. $107 \S 1$ k.p.a., jeśli tylko zawierają minimum elementów niezbędnych do zakwalifikowania ich jako decyzji" ${ }^{12}$. Co zatem istotne treść, nie zaś forma stanowią, czy pismo jest decyzją, czy nie.

W przedmiotowej sprawie nie budzi wątpliwości, iż kurator oświaty jest organem właściwym w sprawie przeniesienia ucznia do innej szkoły. Przenosząc

9 Ustawa z dnia 17 czerwca 1966 r. o postępowaniu egzekucyjnym w administracji (tekst jedn. Dz.U. z 2017 r. poz. 1201).

10 Więcej zob. J. Zimmermann, op. cit., s. 294-298.

11 Więcej zob. M. Laskowska, Decyzja administracyjna, [w:] Leksykon prawa administracyjnego, s. 46-51.

12 Wyrok NSA w Warszawie z 20 lipca 1981 r., SA 1163/81, http://orzeczenia.nsa.gov.pl/doc/ D72F1F5A41 (dostęp: 21.11.2017). 
ucznia do innej szkoły, kurator oświaty rozstrzyga bowiem w jego indywidualnej sprawie o dalszej realizacji przez niego obowiązku szkolnego. A zatem rozstrzyga w zakresie wynikającym z przepisów prawa w sprawie o charakterze administracyjnym. Należy też zaznaczyć, że w sprawie formy, w jakiej kurator oświaty przenosi ucznia do innej szkoły, wypowiedział się Naczelny Sąd Administracyjny w wyroku z 15 lutego 2000 roku $^{13}$. Stwierdzał w nim, że decyzję w sprawie przeniesienia ucznia do innej szkoły wydaje kurator oświaty. Kurator oświaty działa w tej sprawie jako organ pierwszej instancji. Odwołanie od decyzji kuratora oświaty przysługuje stronie, na zasadach ogólnych, do ministra właściwego do spraw oświaty, działającego w tym przypadku jako organ wyższego stopnia.

\section{SKREŚLENIE UCZNIA NIEOBJĘTEGO OBOWIĄZKIEM SZKOLNYM Z LISTY UCZNIÓW}

Odmienne rozwiązania prawne stosuje się w stosunku do ucznia nieobjętego obowiązkiem szkolnym, spełniającego jednak obowiązek nauki. Zgodnie z art. 68 ust. 2 ustawy Prawo oświatowe dyrektor szkoły może, decyzją, skreślić ucznia z listy uczniów w przypadkach określonych w statucie szkoły. Organem właściwym do podjęcia decyzji w przedmiocie skreślenia ucznia $\mathrm{z}$ listy uczniów jest zatem dyrektor szkoły, przesłanki zaś, na podstawie których zostanie wszczęte postępowanie, powinny być określone w statucie szkoły. Decyzji co do skreślenia ucznia z listy uczniów szkoły nie może podjąć żaden inny podmiot, jak chociażby wychowawca czy pedagog szkolny, jak też — w wypadku szkół prywatnych właściciel szkoły. To na dyrektorze spoczywa prawo do rozstrzygania spraw administracyjnych ${ }^{14}$, skreślenie zaś z listy uczniów wyczerpuje znamiona tego typu sprawy. Warto też podkreślić, że do postępowania w przedmiocie skreślenia ucznia $\mathrm{z}$ listy uczniów stosuje się przepisy kodeksu postępowania administracyjnego.

Postępowanie wszczyna z urzędu dyrektor, informując o tym fakcie stronę, wobec której wszczyna postępowanie. W czasie trwającego postępowania w sprawie skreślenia z listy uczniów uczeń jest zobowiązany do przestrzegania swoich praw i obowiązków - przede wszystkim ma prawo chodzić do szkoły, w tym uczestniczyć w zajęciach dodatkowych, o ile nie został zawieszony w prawach ucznia. Nikt nie może kwestionować jego udziału w obowiązkowych zajęciach. W postępowaniu wyjaśniającym dyrektor powinien ustalić stan faktyczny sprawy. Dokonuje tego na podstawie zebranego materiału dowodowego, a następnym krokiem powinno być sprawdzenie, czy dany czyn został uwzględniony w statucie szkoły jako przypadek stanowiący przesłankę do podjęcia decyzji w przedmiocie

13 I SA $1463 / 99$.

14 Por. A.J. Jeżowski, J. Madalińska-Michalak, Dyrektor szkoły - koncepcje i wyzwania. Między teoria a praktyka, Warszawa 2015, s. 56. 
skreślenia. Zgodnie z art. 98 ust. 1 pkt 17 ustawy Prawo oświatowe statut powinien określać „prawa i obowiązki uczniów, w tym przypadki, w których uczeń może zostać skreślony z listy uczniów".

Słuszne wydaje się twierdzenie, że akt prawny w randze statutu szkoły powinien zawierać precyzyjnie określone zasady, także dotyczące relegowania uczniów. Postulat ten wynika z faktu, iż wiele statutów reguluje tę kwestię w sposób bardzo ogólny, co może osłabić prowadzone postępowanie lub podjęcie ostatecznej decyzji ${ }^{15}$. Zgodnie z art. 7 i 77 § 1 k.p.a. dyrektor szkoły, będący organem prowadzącym postępowanie, powinien zebrać oraz należycie ocenić wszelkie dowody w sprawie, w tym opinie i wyjaśnienia strony. Niezwykle istotna jest także dyrektywa art. 81 k.p.a., zgodnie z którą po zebraniu materiału dowodowego dyrektor powinien przedstawić go uczniowi. W ten sposób umożliwia mu wypowiedzenie się co do zebranych dowodów. W innym przypadku okoliczność nie może zostać uznana za udowodnioną.

Kolejnym etapem postępowania w przedmiocie skreślenia ucznia z listy uczniów jest zwołanie przez dyrektora szkoły zebrania rady pedagogicznej. Ewentualne skreślenie ucznia należy dogłębnie przedyskutować, a następnie powinna zostać podjęta stosowna uchwała. Uchwała rady pedagogicznej zapada zwykłą większością głosów w obecności co najmniej połowy jej członków. Inne szczegółowe kwestie związane z głosowaniem określa regulamin rady pedagogicznej. Po podjęciu uchwały dyrektor powinien przedstawić jej treść samorządowi uczniowskiemu. Zgodnie z art. 85 ust. 5 ustawy Prawo oświatowe samorząd uczniowski „może opracować pisemną opinię w tej sprawie”. Zostaje tym samym uruchomiony tryb współdziałania organów w rozumieniu art. 106 k.p.a. Opinia samorządu uczniowskiego powinna zostać przedstawiona niezwłocznie, nie później jednak niż w terminie 14 dni od przekazania żądania o zajęcie stanowiska w formie postanowienia, na które stronie przysługuje zażalenie. Mimo iż opinia nie jest wiążąca dla dyrektora, a zatem nie decyduje o wyniku postępowania, to może mieć w odniesieniu do niego istotne znaczenie, czyniąc decyzję nieważną.

Decyzja dyrektora szkoły o skreśleniu z listy uczniów powinna zostać sformułowana na piśmie zgodnie z wymogami z art. 107 k.p.a. Decyzja na podstawie regulacji art. 110 k.p.a. wiąże zarówno adresata, jak i organ od momentu jej doręczenia. Od tej chwili biegnie też czternastodniowy termin na wniesienie odwołania do organu wyższej instancji. Zgodnie z art. 129 k.p.a. odwołanie wnosi się do właściwego organu odwoławczego za pośrednictwem organu, który wydał decyzję, w terminie 14 dni od doręczenia decyzji stronie, a gdy decyzję ogłoszono

15 Ustawa z dnia 14 grudnia 2016 r. Przepisy wprowadzające ustawę — Prawo oświatowe (Dz.U. z 2017 r. poz. 60) przewiduje różne terminy odnośnie do poszczególnych typów szkół na uchwalenie statutów odpowiadających nowo wprowadzonym zasadom prawa oświatowego. Warto zatem wskazać na większą precyzję w konstruowaniu tych aktów. Co do zasad tworzenia statutów zob. E. Czechowicz, L. Zientecka, Statut szkoły i placówki po zmianie ustroju szkolnego, Warszawa 2017, s. 19-25. 
ustnie — od dnia jej ogłoszenia stronie. Po upływie tego terminu decyzja się uprawomocnia, co skutkuje brakiem możliwości zmiany. Dlatego osoba odbierająca decyzję o skreśleniu z listy uczniów powinna zadbać o potwierdzenie daty jej otrzymania. Odwołanie, jak wskazano, należy złożyć do dyrektora szkoły, który będzie miał siedem dni na odpowiedź albo przekazanie go do wyższej instancji, czyli kuratora. Warto w nim zawrzeć wszystkie argumenty przemawiające za zmianą decyzji. Jeśli kurator utrzyma decyzję, można już tylko walczyć w sądzie.

Nawet bezpośrednio po wydaniu decyzji szkoła nie powinna oczekiwać, że uczeń natychmiast zniknie z jej murów. Skreślonemu przysługuje odwołanie, a zgodnie z art. 130 k.p.a. przed upływem terminu do wniesienia odwołania decyzja nie zostaje wykonana, a wniesienie odwołania w terminie wstrzymuje wykonanie decyzji.

\section{SKREŚLENIE UCZNIA SZKOŁY NIEPUBLICZNEJ A OBOWIĄZEK SZKOLNY}

Uzasadnione wydaje się twierdzenie, że nowa ustawa oświatowa w sposób zdecydowanie marginalny potraktowała zagadnienie szkolnictwa niepublicznego. W ustawie odnoszącej się do szkolnictwa publicznego jedynie jeden z rozdziałów został poświęcony szkołom niepublicznym. Brakuje racjonalnego wytłumaczenia tego typu działań, jako że szkolnictwo niepubliczne cieszy się dużym zainteresowaniem uczniów i ich rodziców, głównie z powodu dobrze pojętej elitarności tych szkół, możliwości skupienia się na indywidualnych potrzebach dzieci oraz zapewnienia im ciekawych zajęćc ${ }^{16}$.

Niezależnie od różnych poglądów na temat szkolnictwa niepublicznego należy przypomnieć, że szkoły niepubliczne - na co wskazuje w art. 8 ust. 1 ustawy z dnia 14 grudnia 2016 roku Prawo oświatowe - są jednym z elementów systemu oświaty. Mimo że podjęcie nauki w tego typu szkołach wiąże się z zawarciem stosownego kontraktu cywilnoprawnego, to nie ma wątpliwości, że także w wypadku tych szkół dochodzi do powstania stosunku opartego na administracyjnoprawnej metodzie regulacji ${ }^{17}$.

Odnośnie do szkół niepublicznych problematyka skreślenia ucznia z listy uczniów uregulowana została w art. 172 ust. 2 pkt 5 ustawy Prawo oświatowe. Zgodnie z tym przepisem ,szkoła [...] działa na podstawie statutu nadanego przez osobę prowadzącą". Przepis ten w ust. 2 zawiera katalog spraw, które statut szkoły niepublicznej powinien określać, w szczególności nazwę i typ szkoły, osobę prowa-

16 https://plus.gs24.pl/wiadomosci/a/szkoly-niepubliczne-musza-same-sobie-radzic-w-reforma oswiaty,11441129 (dostęp: 21.12.2017).

17 Więcej zob. M. Szubiakowski, Administracyjnoprawna regulacja praw $i$ wolności obywatelskich, Warszawa 2017. 
dzącą, organy szkoły oraz zakres ich zadań, jak również organizację szkoły. Istotne są także prawa i obowiązki uczniów szkoły, w tym przypadki, w których uczeń może zostać skreślony z listy uczniów szkoły niepublicznej. Jak widać, w statucie szkoły niepublicznej powinny być zawarte „określone przypadki” stanowiące przesłanki do skreślenia ucznia z listy uczniów. Dodatkowo powinny one być określone w taki sposób, żeby nie budziły żadnej wątpliwości przy rozstrzyganiu konkretnej sprawy. Zatem tylko w tych odnośnych, enumeratywnie wymienionych w statucie szkoły niepublicznej przypadkach może nastąpić skreślenie ucznia.

Statut szkoły może wskazywać różne przypadki stanowiące przesłankę skreślenia ucznia z listy uczniów szkoły niepublicznej. Jak wskazuje jednak znaczna część prowadzonych postępowań, najczęstszą przesłanką jest niewywiązywanie się rodziców ucznia z obowiązku uiszczania tak zwanego czesnego za naukę lub nieprzestrzeganie statutowych zasad właściwego zachowania się ucznia, polegające na agresywnym zachowaniu się godzącym w zdrowie i bezpieczeństwo pozostałych uczniów. Warto tu przytoczyć wyrok Sądu Najwyższego uznający, iż:

W wypadku, gdy rodzice dziecka objętego obowiązkiem szkolnym dokonali dobrowolnego wyboru odpłatnego trybu realizacji tego obowiązku w niepublicznej szkole, a następnie nie wywiązują się wobec szkoły niepublicznej z przyjętego na siebie obowiązku opłaty kosztów nauki świadczonej na rzecz ich dziecka (tzw. czesnego), dyrektor szkoły niepublicznej może podjąć decyzję o skreśleniu dziecka z listy uczniów szkoły ${ }^{18}$.

Jeżeli — jak w opisanej sytuacji — spełnione zostaną określone w statucie szkoły niepublicznej przesłanki prawne uzasadniające skreślenie ucznia z listy uczniów tej szkoły, wówczas można skreślić ucznia, nawet jeżeli jest on objęty obowiązkiem szkolnym. W tym przypadku dyrektor szkoły nie jest związany ograniczeniem ustawowym wynikającym z art. 68 ust. 3 ustawy Prawo oświatowe, przepis ten dotyczy bowiem wyłącznie uczniów szkół publicznych.

Osobą uprawnioną do wszczęcia postępowania administracyjnego zmierzającego do skreślenia z listy uczniów jest dyrektor szkoły. Istotne jest, że po podjęciu decyzji o skreśleniu dyrektor szkoły niepublicznej obowiązany jest poinformować o tym dyrektora szkoły publicznej, w której obwodzie dziecko mieszka, w celu umożliwienia skutecznego sprawowania kontroli dopełnienia przez rodziców obowiązku zapewnienia dalszej realizacji obowiązku szkolnego dziecka. Obowiązek ten wynika z faktu, iż dyrektor szkoły niepublicznej pełni zarazem funkcję urzędnika państwowego, który musi partycypować w sprawowaniu kontroli dopełnienia przez rodziców obowiązku zapewnienia realizacji obowiązku szkolnego dziecka ${ }^{19}$.

18 Wyrok Sądu Najwyższego z dnia 9 listopada 2001 r., III RN 149/2000, OSNAPiUS 2002, nr 7, poz. 153.

19 Por. ibidem. 
Skreślenie ucznia z listy uczniów szkoły niepublicznej powinno następować w wyniku decyzji administracyjnej ${ }^{20}$. Konieczne elementy decyzji administracyjnej reguluje art. $107 \S 1$ kodeksu postępowania administracyjnego, przy czym oczywiste jest, że nie forma, lecz treść przesądza o tym, czy dany akt jest decyzją administracyjną. Organem odwoławczym od decyzji dyrektora szkoły niepublicznej o skreśleniu ucznia z listy uczniów jest kurator oświaty. Na jego decyzję przysługuje skarga do sądu administracyjnego.

Jako problem końcowy warto podnieść zagadnienie pełnej współpracy między dyrektorem szkoły niepublicznej a uczniem, a zwłaszcza rodzicami ucznia. Rodzice nie zawsze mają wiedzę, że dyrektor szkoły nie podlega wszystkim regulacjom, które zawiera ustawa Prawo oświatowe. Zatem zasadne wydaje się, przy okazji zapoznawania ich z obowiązującymi dokumentami szkoły, zwrócenie szczególnej uwagi na statut częściowo regulujący te kwestie, które w przypadku szkół publicznych reguluje ustawa oświatowa.

W tym kontekście warto przywołać tezę wyroku NSA z 2000 roku i - co wydaje się uzasadnione — poddać ją krytyce. Sąd przyjął bowiem, że także w niepublicznej szkole podstawowej uczeń za naruszenie przepisów statutu szkoły może zostać jedynie przeniesiony do innej szkoły, a nie skreślony z listy uczniów ${ }^{21}$. Najwyraźniej w rozstrzygnięciu nie wzięto pod uwagę systematyki ustawy Prawo oświatowe.

Trzeba też wskazać na sytuację, gdy treść umowy z rodzicami pozwala na jej rozwiązanie przez szkołę lub organ prowadzący. Jak trafnie zauważył sąd pierwszej instancji:

uczeń szkoły niepublicznej nawiązuje dwa równoległe i wewnętrznie sprzężone stosunki prawne: cywilnoprawny (który opiera się na umowie o naukę łączącej go z osobą prowadzącą placówkę) i administracyjnoprawny (łączący go bezpośrednio ze szkołą). Wobec powyższego stosunek administracyjny jest niejako stosunkiem wtórnym w odniesieniu do kontraktu cywilnego zawartego przez strony. Jego istnienie uzależnione jest od ważnej umowy łączącej strony. W skutecznym rozwiązaniu umowy cywilnej relacja administracyjna (przejawiająca się podległością ucznia w stosunku do szkoły) zostaje przerwana, co oznacza, że od tej chwili słuchacz nie ma obowiązku poddania się regulacjom wewnętrznym szkoły (przede wszystkim statutowi). Rozwiązanie stosunku cywilnego w sposób oczywisty oddziałuje na relację administracyjną. Skuteczne rozwiązanie umowy powoduje, że nie jest konieczne dodatkowe skreślenie z listy uczniów, gdyż stosunek administracyjny łączący ucznia ze szkołą rozwiązuje się wraz z zakończeniem obowiązywania umowy cywilnoprawnej22.

${ }^{20}$ Uchwała Sądu Najwyższego z dnia 18 października 1995 r., III AZP 28/95, OSNAPiUS 1996, nr 11, poz. 149.

21 Wyrok Naczelnego Sądu Administracyjnego z dnia 15 lutego 2000 r., I SA 1463/99, LEX nr 55782.

22 Wyrok NSA z dnia 14 października 2015 r., I OSK 2098/15, http://orzeczenia.nsa.gov.pl (dostęp: 21.12.2017). 
Trzeba jednak pamiętać, że brak odpowiednich zapisów w statucie szkoły lub umowie z rodzicami może spowodować, że zarówno skreślenie z listy uczniów, jak i rozwiązanie umowy (na przykład na podstawie art. 5 k.c. z powodu niemożliwości zapewnienia uczniowi bezpieczeństwa w szkole) będą mogły być kwestionowane przez rodziców.

\title{
UWAGI KOŃCOWE
}

Szkoły publiczne, jak też niepubliczne zobowiązane są do prowadzenia działalności dydaktycznej, opiekuńczej i wychowawczej. Te trzy elementy muszą współgrać, jednak bywają sytuacje, kiedy w procesie oświatowym któryś z nich (względnie wszystkie) nie jest odpowiednio przyswajany przez ucznia. Wówczas może zachodzić przesłanka do przeniesienia ucznia lub jego skreślenia z listy uczniów. Nie wchodząc już tu w szczegółowe zagadnienia prawne, z całą mocą należy podkreślić, że przeniesienie ucznia, zwłaszcza zaś jego skreślenie, powinno być wyjątkowe. Bez wątpienia będzie to miało znamiona traumy zarówno u ucznia, jak i jego rodziców. $Z$ tego powodu działania zmierzające do przeniesienia lub relegacji należy przeprowadzić w ostateczności, po wyczerpaniu wszystkich innych środków, w tym pomocy psychologiczno-pedagogicznej.

Kolejny postulat dotyczy konieczności zapoznania przez szkołę rodziców uczniów i ich samych z przesłankami, które mogą stanowić o przeniesieniu lub skreśleniu ucznia. Trzeba bowiem pamiętać, że nie dla wszystkich przepis prawa bywa jasny. Dodatkowo w różnej prawnie sytuacji szkół publicznych i niepublicznych oraz odmiennej sytuacji uczniów objętych obowiązkiem szkolnym i niewypełniających tego obowiązku wyjaśnienie zagadnienia wydaje się podstawowe.

\section{DELETION OF A STUDENT FROM THE LIST OF STUDENTS AND SCHOOL DUTY}

\author{
Summary
}

The article "Deletion of a student from the list of pupils and school duty" presents the problem of student relocation or relegation. This is a complex problem. The final solution depends on many factors. The basic ones are the type of school as well as the age of the student, which in turn is associated with the concept of compulsory schooling and the obligation to learn. Taking into account the fact that the transfer, and the more the removal of the student from the school, causes specific legal decisions, it is worth to familiarize the school community with the premises and consequences of these activities.

Keywords: educational law, compulsory education, obligation to learn, deletion of a student, transfer of a student, proceedings and administrative decision 


\section{BIBLIOGRAFIA}

Brzeski M., Tykwińska-Rutkowska D., Zakład administracyjny, [w:] Leksykon prawa administracyjnego, red. E. Bojanowski, K. Żukowski, Warszawa 2009.

Bułajewski S., Dąbrowski M., Wolności i prawa człowieka w Konstytucji Rzeczypospolitej Polskiej, red. M. Chmaj, Warszawa 2008.

Czechowicz E., Zientecka L., Statut szkoty i placówki po zmianie ustroju szkolnego, Warszawa 2017.

Jeżowski A.J., Madalińska-Michalak J., Dyrektor szkoty — koncepcje i wyzwania. Między teoria a praktyka, Warszawa 2015.

Laskowska M., Decyzja administracyjna, [w:] Leksykon prawa administracyjnego, red. E. Bojanowski, K. Żukowski, Warszawa 2009.

Skrzydło W., Konstytucja Rzeczypospolitej Polskiej z dnia 2 kwietnia 1997 r. Komentarz, Kraków 1998.

Sztejna P., Prawne aspekty obowiazku szkolnego i obowiązu nauki, „Studia Lubuskie” 2005, nr 1.

Szubiakowski M., Administracyjnoprawna regulacja praw $i$ wolności obywatelskich, Warszawa 2017.

Zimmermann J., Prawo administracyjne, Warszawa 2014. 